\title{
CALDERÓN, ¿UN DATO ESCONDIDO EN LA POESÍA DE BORGES?
}

Rocío Arana

Facultad de Educación Universidad Internacional de La Rioja

Gran Vía Rey Juan Carlos I, 41 26002 Logroño, La Rioja. España rocio.arana@unir.net

María Caballero Facultad de Filología Universidad de Sevilla

C/ Palos de la Frontera, S/N 41004 Sevilla. España mcaballero@us.es

[Anuario calderoniano (ISSN: 1888-8046), 7, 2014, pp. 53-79]

Calderón y su pervivencia en el siglo xx... Borges y el Barroco: amores y desamores tantas veces glosados por los críticos y que sin embargo siguen dejando lagunas, espacios oscuros por explorar, por ejemplo sus posibles lecturas de Calderón durante la estancia en España (1919-1921) en momentos previos al rescate de Góngora.Ya de vuelta a su país, en su primer artículo (El Diario Español, Buenos Aires, 23 
de octubre de 1921), saluda al ultraísmo como genuinamente hispano, heredero de un Barroco que admira por su creatividad:

... la tendencia a escribir en sucesión de imágenes — tendencia que Machado apunta como la exteriorización más resaltante de la lírica ultraica - campea en nuestros clásicos, y no solo en poetas conscientemente marginales y banderizos como don Luis de Góngora, sino en Calderón, en Baltasar Gracián, y con principalísimo relieve, en Quevedo ${ }^{1}$.

El texto, farragoso y con afirmaciones vehementes propias de la juventud, se brinda a sabrosos comentarios por la parcialidad con que enjuicia a los clásicos. El recorrido hacia el desprecio del Ultra es relativamente breve y muy conocido. Nos desviaría de nuestro propósito, para el que sin embargo es significativa la referencia a Calderón. Porque, debido a las concomitancias del famoso sintagma «la vida es sueño» con tantos de sus versos, resulta casi inevitable preguntarse si el argentino leyó a Calderón.

$\mathrm{Y}$ es que, curiosamente, tienen algunos puntos en común que suelen darse por supuestos en Borges, pero los críticos de la última década aplican también al español: la atención a la estructura de sus obras, sumamente pensada y cuidada $^{2}$. O la reescritura de sus textos, obvia en La vida es sueño, una idea volcada en tres moldes: la famosa comedia (1636) y dos autos sacramentales ya de los setenta. Y, además, ambos son poetas. Por lo que se refiere al escritor barroco, no tanto por su poesía exenta, comparativamente escasa, sino por la poesía diseminada en su teatro, entreverado de coplas, romances, sonetos... ya sea en el registro culto o el popular. Por fin, comparten una sólida formación intelectual reflejada en la obra, en temas como «la vida sueño» y «el libre albedrío», tan significativos en ambos escritores.

En consecuencia y para este artículo, nos impusimos repasar la poesía borgesiana y sus primeros textos (Textos cautivos, Textos recobrados... cartas y testimonios de la estancia europea...) en busca de alguna referencia al respecto. Sin éxito aparente. Si acaso, un leve apunte

${ }^{1}$ Borges, 1997, p. 108.

2 «Todos los detalles están relacionados de manera férrea y el encadenamiento de las acciones no deja flecos sueltos», dice Arellano para la comedia protagonizada por Segismundo (2001, p. 77). 
tangencial del escritor maduro en Siete noches, ciclo de conferencias en que la imaginación onírica se hace presente:

Para el salvaje o para el niño los sueños son un episodio de la vigilia, para los poetas y los místicos no es imposible que toda la vigilia sea un sueño. Esto lo dice de modo seco y lacónico, Calderón: «La vida es sueño». Y lo dice, ya con una imagen, Shakespeare: «Estamos hechos de la misma madera que nuestros sueños» ${ }^{3}$.

En segunda instancia, revisamos la bibliografia secundaria, especialmente biografias y entrevistas. Los volúmenes colectivos o actas de congresos como el de Cuadernos Hispanoamericanos (1992) no tocan este tema. Y ello a pesar de contar con un prometedor artículo de Loreto Busquets sobre "Borges y el Barroco». Un libro anterior, Borges en España (1990), coordinado por Fernando R. Lafuente tampoco lo nombra a lo largo de sus ocho artículos. No vale la pena seguir rememorando la búsqueda bibliográfica... Al fin aparecieron referencias, breves pero directas, en la conversación mantenida con Sorrentino en los setenta. Allí el maduro escritor argentino recupera y a la vez marca distancias con el escritor barroco a quien considera encorsetado en estructuras moralistas:

En cuanto a la versificación de Calderón, la encuentro excesivamente pobre y será, quizá, porque no lo he leído bien, pero el hecho es que yo no puedo distinguir un personaje de otro, y me parece que se nota demasiado el mecanismo teatral en sus obras. Y lo mismo puede decirse de todo el teatro clásico español. Ya sé que estoy diciendo una herejía ${ }^{4}$.

Palabras previsibles en el escritor consagrado siempre deseoso de escandalizar diciendo alguna boutade... Más interesantes resultan los matices sobre el sentido del sintagma «la vida es sueño» aplicado a Calderón y Shakespeare:

Cuando Shakespeare, por ejemplo, equipara la vida con un sueño, él, en lo que insiste es en la irrealidad de la vida, en el hecho de que es dificil fijar una diferencia entre lo que soñamos y lo que vivimos. En cam-

3 Borges, 1999c, p. 39.

4 Sorrentino, 2001, p. 133. 
bio, en el caso de Calderón, creo que la frase tiene un sentido teológico: la vida es sueño, en el sentido de que nuestra vida, nuestra vigilia, no corresponden a la realidad, sino a una breve parte de la realidad, el sentido de que lo verdadero son el cielo y el infierno ${ }^{5}$.

Y remacha una y otra vez:

La idea de Calderón es una idea religiosa, o, mejor dicho, una idea cristiana. Creo que Calderón le daba el énfasis a la idea de lo transitorio de la vida, comparado con lo transitorio de un sueño ${ }^{6}$.

¿Tiene razón el argentino en sus planteamientos cuando contrapone la raíz religiosa calderoniana a su propia cosmovisión e intencionalidad poética? ¿Cómo funcionan, en los textos de ambos, mensajes tan aparentemente opuestos como libre albedrío/fatum, religiosidad moderna/increencia postmoderna? Ese es el objetivo de nuestro trabajo.

Pero antes conviene seguir rastreando cómo accede el porteño al escritor barroco, dato escondido de su obra. En cuanto a la faceta de espectáculo teatral, las obras de Calderón se representaron en Buenos Aires desde el xIX. En concreto están documentadas La vida es sueño (1936, Teatro Odeón), El alcalde de Zalamea (1939, compañía de Margarita Xirgu) y El gran teatro del mundo (1940, Agrupación Argentina de Estudios Escénicos) ${ }^{7} \ldots$ ¿Asistió entonces Borges a alguna de ellas? No hemos podido constatarlo, pero no sería extraño que se deleitara con los versos del maestro a pesar de la displicencia que muestra al hablar con Sorrentino.

Si nos atenemos a las lecturas del escritor, la respuesta es fácil. Hay dos autores, Schopenhauer y Unamuno, que pudieron servirle de voceros en épocas distintas y con impactos no equiparables. En absoluto sorprende que el joven Borges se dejara captar por el salmantino,

5 Sorrentino, 2001, p. 133.

6 Sorrentino, 2001, p. 133.

7 Junto a un largo etcétera en los sesenta, setenta y ochenta, que llega hasta 1999, en que Suárez Marzal dirige una nueva versión de La vida es sueño... Hubo además presentaciones radiofónicas en los cincuenta (Radio del Estado, interpretadas por Las dos Carátulas). 
como ya ha sido trabajado ${ }^{8}$. En Niebla (1914) encontraría, no un alma gemela, pero sí preocupaciones metapoéticas y metafisicas que cada uno resolverá a su modo. Es más que probable que una frase leída al azar en Del sentimiento trágico de la vida (1913), «la filosofia está líquida y difusa en nuestra literatura ${ }^{9}$, haya removido sus viejas convicciones heredadas del ultraísmo. Máxime cuando para demostrarlo Unamuno comenta cuatro obras y una de ellas es La vida es sueño. ¿Hasta qué punto pudo pesar esa lectura en el cambio poético, en la distancia que media de "Gesta maximalista» (con su elogio vanguardista a la revolución rusa) a "El truco», cuajado de implicaciones metafisicas (el tiempo, la identidad, el libre albedrío...)?

Por lo que se refiere a Schopenhauer, las múltiples referencias al alemán espolvoreadas por sus obras ${ }^{10}$ dan fe de algo bien conocido, su fascinación por el filósofo alemán: «En algún momento en Suiza comencé a leer a Schopenhauer - declara-. Hoy, si tuviera que escoger a un solo filósofo, lo escogería a él. Si el enigma del universo pudiera ponerse en palabras, creo que esas palabras estarían en sus textos ${ }^{11}$. En consecuencia, los editores de Un ensayo autobiográfico fotografian su ejemplar de Schopenhauer, Der Welt als Wille und Vorstellung... publicado en Múnich (1912) y le añaden un pie de página que dice: «La frase — resumen de su filosofia idealista - El mundo es mi idea del mundo, y el escepticismo pesimista de su moral influirían decisivamente en Borges, que escribió: Si el enigma del universo puede reducirse a palabras, creo que esas palabras se encuentran en sus obras» ${ }^{12}$.

Por fin respecto a la relación de ambos escritores, declaraciones del argentino a fines de los sesenta confirman nuestro planteamiento:

8 Fernández, 1990; Caballero, 2007.

9 Unamuno, 1969, p. 290.

${ }^{10}$ La relación de Borges y Schopenhauer sería otro trabajo, por lo demás en gran medida ya explorado. La última tesis que conozco de la Universidad Complutense de Madrid, Schopenhauer, Nietzsche, Borges y el eterno retorno (2007), de Javier Acosta Escareño revisa las múltiples referencias borgesianas al alemán desde Fervor de Buenos Aires en adelante, pasando por Evaristo Carriego, Discusión, Historia de la eternidad, Ficciones, El Aleph: (Borges, 1989, I, pp. 13, 38, 161, 199, 258, 351, 383, 438, 462, 483, 577); y Otras inquisiciones (Borges, 1989, II, pp. 24-27, 57, 80, 95-97, 115-117, 138).

11 Borges, 1999a, p. 40.

12 Borges, 1999b, p. 48. Los editores citan mal a Borges... 
Creo que dije que Calderón de la Barca era una invención de los alemanes; creo que dije que el título de la obra La vida es sueño hizo que se lo considerara como poeta metafísico. Esto se encuentra en El mundo como voluntad $y$ representación, de Schopenhauer, y Schopenhauer habla de la esencia onírica de la vida ${ }^{13}$.

Evidentemente, Calderón y Schopenhauer en absoluto son intercambiables, más bien están en las antípodas. Pero la lectura del segundo pudo abrir los ojos al joven argentino y ponerle en contacto con temas que luego desdoblará y reduplicará: la indeterminación de las fronteras vida/sueño y el libre albedrío. Un asunto este último que, habiéndose educado en la ciudad y el colegio de Calvino ${ }^{14}$ no pudo dejarle indiferente. Aún menos si recordamos su formación siempre a caballo entre la Biblia protestante de la familia paterna y el profundo catolicismo de doña Leonor. De entrada, la solución a estas cuestiones enfrentará a Calderón y Borges, aunque se trata de una madeja sutil por su complejidad filosófica que desborda los límites de nuestro trabajo. Quisiéramos al menos contraponer algunos versos borgesianos a otros de La vida es sueño o El mágico prodigioso para dejar insinuados los matices que se vislumbran a partir de la creación literaria de ambos monstruos.

LOS PERFILES DE UN SINTAGMA: «LA VIDA ES SUEÑO»

A la hora de perfilar posibles fuentes literarias para esta obra en concreto, nos remitimos a lo escrito por Arana Caballero al editar la comedia hace algunos años:

13 Sorrentino, 2001, pp. 132-133. Es bien conocida la fascinación de los románticos alemanes con el Barroco español. Ya Goethe veneraba a Calderón (y Borges ha leído a Goethe). De Schopenhauer se sabe que aprendió castellano precisamente para leer al citado escritor en su lengua nativa. Años después Borges haría lo mismo sólo que al revés: estudiaría alemán para leer en la lengua propia a los románticos alemanes.

14 Brillante la recreación narrativa de la época que hace Stefan Zweig en su libro sobre Calvino, con las disputas entre el catolicismo y los nuevos brotes protestantes. 
Yo diría que existe una fuente a priori y otra a posteriori, del mismo modo en que el propio Calderón distinguía en una obra el asunto y el argumento. Una cosa es la anécdota que enciende la chispa de la creación en un instante dado, y otra la finalidad íntima, pensada y planificada, que mueve a un dramaturgo a escribir lo que escribe. La leyenda del durmiente despierto pertenece al folklore, y según Cilveti, se remonta a Las mil y una noches. En España adquiere forma escrita con uno de los cuentos de Don Juan Manuel y en una carta de Luis Vives. La historia del borracho que fue llevado dormido a la cama de un duque, servido como un duque por todo un día y después devuelto a su pobreza, fue dramatizada también por Shakespeare y por Agustín de Rojas, pero ambos le dan un tratamiento burlesco, mientras Calderón la eleva a símbolo de la condición humana ${ }^{15}$.

Tanto Calderón como Borges eligen por sus implicaciones antropológicas e incluso metafísicas un motivo muy conocido. Inútil insistir en las fuentes del primero, síntesis de tradiciones, como ya vio Regalado. Sería interesante recordar que Las mil y una noches fue libro de cabecera del argentino y Shakespeare, uno de sus autores más citados. Incluso escribirá un poema, «Metáforas de las Mil y una Noches», en que señala el sueño como una de las cuatro metáforas esenciales que articulan el mítico libro ${ }^{16}$. Bien es verdad que, para acceder a esos temas, no necesita depender de un Calderón que le llega de segunda mano (los alemanes).

Como marco contextual del joven Borges, no hay que olvidar Die Traumdeutung (La interpretación de los sueños), de Freud, que abrió al psicoanálisis la subjetividad del paciente y causó enorme revuelo. Pero el artificio literario del sueño hunde sus raíces en la noche de los tiempos, bien como oráculo de los dioses para predecir el futuro (Escipión), como recurso ficcional para la sátira (Lipsius, Quevedo), como vía de acceso para lo maravilloso (Shakespeare), o indagación metafísica de mayor calado (Sor Juana Inés de la Cruz, Gorostiza...). Muchas de estas cuestiones fueron recordadas por Lía Schwartz en su artículo «De

15 Arana Caballero, 2009, p. 11.

16 Borges, 1989, III, pp. 169-170. «La tercera metáfora es el sueño / Agarenos y persas lo soñaron [...] / El sueño se disgrega en otro sueño / Y ése en otro y en otros, que entretejen / Ociosos un ocioso laberinto. En el libro está el Libro»... (Borges, 1989, III, p. 170). 
la imaginación onírica en La vida es sueño", uno de los pocos trabajos que entrelazan Calderón y Borges, aunque su finalidad sea presentar al escritor barroco como neoestoico. Tras recurrir a Corominas para explicar la bisemia de «sueño» («somnus»=«el acto de dormir» y «somnium»=«la representación de sujetos imaginados durmiendo»), plantea su tesis:

Los antiguos estoicos y neoestoicos de los siglos XVI y XVII transmitieron sus preceptos éticos jugando con estas imágenes de la inanidad de los deseos o del sueño de la vida. El sintagma dialogaba a veces con otras metáforas también muy reiteradas en los manuales estoicos: por ejemplo, la comparación tópica de la vida del hombre con la representación tea$\operatorname{tral}^{17}$.

El gran teatro del mundo calderoniano parece haberse escrito para certificar esta teoría. El dramaturgo conoció con seguridad la clasificación de los sueños del griego Artemidoro, que vivió en el siglo segundo, pero cuyas teorías — sigue diciendo Schwartz- «se difundirían en la Edad Media latina y europea gracias al comentario compuesto por Macrobio del Somnium Scipionis, que Cicerón incorporó en su De re publica», de gran impacto hasta el XIX. Según ellos, los sueños se dividen en dos tipos: el sueño enigmático / visión profética / oracular, por un lado; y por otro, la pesadilla ${ }^{18}$. Ambos se cumplirán en Segismundo. Además, en la corte madrileña de 1620-1640, estaban vigentes (Erasmo, Séneca, Lipsius, Quevedo) doctrinas como «la razón es la que guía a los hombres a la constancia», muy patente en La vida es sueño. $\mathrm{O}$ "solo el verdadero sabio reconoce la fantasía de los sentidos; y el engaño y desengaño subsiguientes son parte del proceso que lleva al dominio de las emociones a través de la prudencia». Idea también presente en la comedia.

Pudiera ser así y Schwartz documenta el método de interpretación de los sueños de Artemidoro difundido por Macrobio en las palabras de Clotaldo, un personaje que también ha sido presa de la duda acerca de lo que ve: «iVálgame el cielo! ¿Qué escucho? / Aún no sé de-

17 Schwartz, 2012, p. 2.

18 Para el Xvi circulaban versiones latinas e italianas de Artemidoro, por lo que el acceso a las fuentes era fácil. 
terminarme / si tales sucesos son/ ilusiones o verdades» (vv. 395-398). Pero, afianzándose poco a poco en su razón, casi al final del acto II exclama:

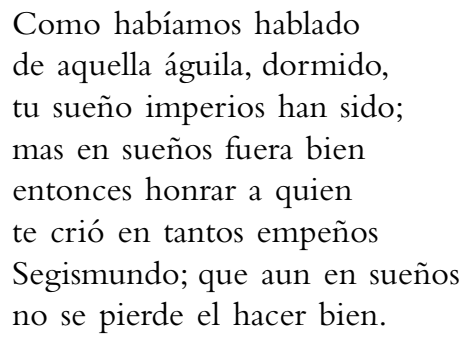

Palabras que preceden al famoso soliloquio de Segismundo (vv. 2148-2187). Un soliloquio que en cuanto a los escurridizos límites entre realidad y sueño no tiene parangón; hasta el punto de resultar manido y necesitar del lector / espectador un plus de inocencia, tras haberse despojado de los prejuicios subsiguientes al bombardeo cultural:

Que el vivir solo es soñar, y la experiencia me enseña que el hombre que vive sueña lo que es hasta despertar. [...] $\mathrm{Y}$ en el mundo, en conclusión todos sueñan lo que son aunque ninguno lo entiende. Yo sueño que estoy aquí destas prisiones cargado, y soñé que en otro estado más lisonjero me vi.

¿Qué es la vida? Un frenesí. ¿Qué es la vida? Una ilusión, una sombra, una ficción, y el mayor bien es pequeño, que toda la vida es sueño y los sueños, sueños son. 
Por el momento, dejemos a un lado la filosofia, a la que retornaremos después para completar la cosmovisión calderoniana, en absoluto plana. Un estudioso polaco ha recordado algo obvio, que el dramaturgo... «antes y después de escribir su obra cumbre, o sea, $L a$ vida es sueño, esboza el tema (motivo) del sueño en sus poesías sueltas, en las obras dramáticas escritas en colaboración con otros autores, en los dramas, comedias, autos sacramentales ${ }^{19}$.Y ejemplifica cuatro sentidos del sintagma presentes en su obra mayor: la vida como sueño o fugacidad; el sueño como imagen de la muerte; el sueño como premonición (sueño profético); y el sueño como vida eterna... sin contar con otras facetas, por ejemplo el uso del sueño como personaje dramático en los autos sacramentales. Un asunto al que volveremos en el último apartado.

Con respecto al sintagma «la vida es sueño», la riqueza y complejidad textual de Borges deja atrás a un Calderón comprometido con la máquina escénica, con ese espectáculo casi total que es el teatro barroco. Espacios, juegos de luces y sombras, engaños y desengaños, damas ultrajadas en busca de su honor... El teatro no parece haber tentado a fondo la voracidad intelectual del argentino, mucho más torturado por cuestiones metafisicas en las que dice descreer, pero tan centrales en su vida que desvían su creación literaria. No por obvios pueden olvidarse poemas tan decisivos como «El truco», "Caminata» o "Amanecer», de Fervor de Buenos Aires, que dinamitan su herencia ultraísta.

Dios, mundo, yo y libro ${ }^{20}$ son los elementos que se relacionan con el sueño en la poesía de Borges, en una ficticia jerarquía que trastabillará en ocasiones. Su tesitura ontológica es prácticamente la misma, al punto de ser intercambiables: mundo como sueño divino; mundo como sueño compartido por la humanidad; mundo como sueño / vigilia del yo poético; texto identificado con referentes empíricos o, más bien, con los recuerdos que generan en los seres humanos ${ }^{21}$. La literatura como sueño dirigido... Aunque muy conocidos, vamos a

19 Sabik, 1998, p. 109.

20 Arana, 1994.

21 «Me pregunto / Si aquel tumulto de oro en la montaña / Fue verdadero o no fue más que un sueño. / Inútil repetirme que el recuerdo / De ayer y un sueño son la misma cosa» (Borges, 1989, III, p. 175). 
reseñar algunos versos para refrescar la memoria del lector no especialista. Inevitablemente, esta pequeña antología se abre con «Amanecer», el temprano poema de Fervor de Buenos Aires:

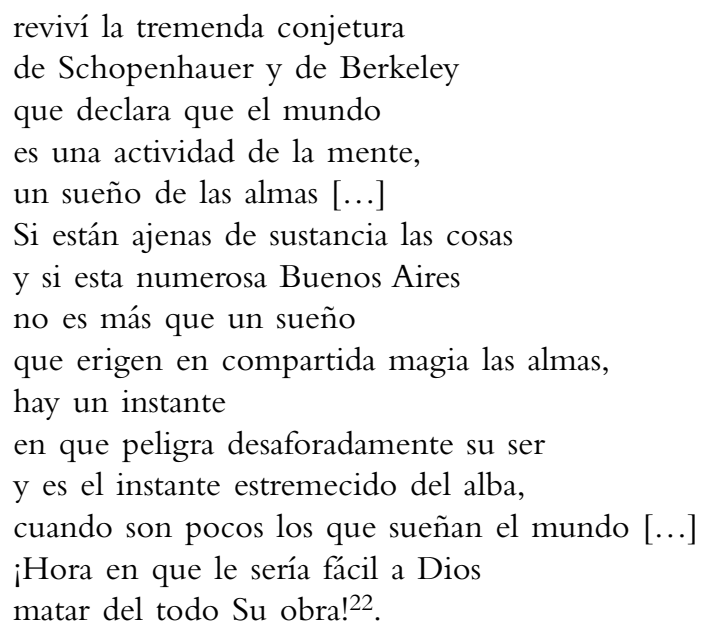

Poema que contiene claves reescritas una y otra vez hasta su muerte, en un proceso de fractura y diseminación de los núcleos iniciales: Schopenhauer como fuente; el mundo como sueño compartido ${ }^{23} \mathrm{o}$ como creación de un dios soñador, o de un yo poético, empeñado en la titánica tarea de Sísifo: soñar una y otra vez, sin desmayos, para que no se pulverice su creación. Muchos años después, en «Oda escrita en 1966» - hoy parte de El otro, el mismo - introduce un abrupto paréntesis en una larga divagación sobre la patria:

\section{(Si el Eterno}

Espectador dejara de soñarnos

Un solo instante, nos fulminaría

Blanco y brusco relámpago, Su olvido $)^{24}$.

22 Borges, 1989, I, pp. 38-39.

23 «Entra la luz y asciendo torpemente / De los sueños al sueño compartido» (Borges, 1989 II, p. 272).

24 Borges, 1989, II, p. 316. 
Del miedo al no-ser como fruto de la inactividad del Soñador por antonomasia, a la imploración lírica al mismo, a la súplica por el ser:

\author{
Ni siquiera soy polvo. Soy un sueño \\ Que entreteje en el sueño y la vigilia \\ Mi hermano y padre, el capitán Cervantes $[\ldots]$ \\ Para que yo pueda soñar al otro \\ Cuya verde memoria será parte \\ De los días del hombre, te suplico: \\ Mi Dios, mi soñador, sigue soñándome ${ }^{25}$.
}

Cadena de soñadores, tan visible en relatos tan famosos como «Las ruinas circulares» y que entrelaza en un amplísimo arco al Dios ya implorado, aparente primer demiurgo, y al ser de ficción, Quijano, sueño de Cervantes en una larga cadena de textos. Este último motivo, («El hidalgo fue un sueño de Cervantes / Y don Quijote un sueño del hidalgo» $\left.{ }^{26}\right)$, en su compleja relación de ida / vuelta es uno de los más reiterados en la poesía de Borges ${ }^{27}$. Sorprende hasta qué punto le impactó la lectura en inglés de ese primer Quijote y cómo transfiere muchos de los motivos en torno al sueño que hoy nos suenan como «calderonianos». Motivos también aplicables a Cervantes o Shakespeare: ¡Qué más da! El culturalismo absorbe otros nombres siempre con la misma dinámica: «la soñó Shakespeare / Y seguirán soñándola los hombres / Y es uno de los hábitos del tiempo / Y un rito que ejecutan en la hora / Predestinada unas formas eternas» ${ }^{28}$. En último término y al final de la cadena, el soñador es el mismo poeta, bien directamente o camuflado tras las máscaras literarias con las que se identifica: «Heráclito no tiene ayer ni ahora. / Es un mero artificio que ha soñado / Un hombre gris a orillas del red Cedar, / Un hom-

25 Borges, 1989, III, pp. 177-178.

26 Borges, 1989, II, p. 94.

27 «Lectores» (Borges, 1989, II, p. 270), «Miguel de Cervantes» (Borges, 1989, III, p. 91), «Sueña Alonso Quijano» (Borges, 1989, III, p. 94), «El testigo» (Borges, 1989, III, p. 112), «Ni siquiera soy polvo» (Borges, 1989, III, p. 177), «La trama» (Borges, 1989 III, p. 461), «Alguien soñará» (Borges, 1989, III, p. 473)... En cuanto a la bibliografia secundaria, Madrid, 1987; De Toro, 1999; Fine, 2003; Caballero Wangüemert, 2007 ..

28 Borges, 1989, III, p. 149. 
bre que entreteje endecasílabos ${ }^{29}$. Un poeta demiurgo capaz de engendrar a un filósofo de la Antigüedad en el texto, porque ni personas ni cosas tienen entidad empírica, sustancia tangible para un ser humano incapaz de percibir su diferencia ontológica.

En cualquier caso, y es lo que interesa ahora, el sintagma «la vida es sueño" calderoniano, de indudable hondura, resulta monolítico y parco frente a la explosión de sentido en múltiples facetas complementarias del poeta argentino. Los tres siglos transcurridos imprimieron su huella, generando una plurisemia que enriquece el texto, aunque inquiete al ser humano hasta límites imprevisibles. Ya no es solo el tempus fugit de una vida que se identifica con la vigilia sino que, al modo barroco, se refracta en espejos, ese símbolo tan inquietantemente borgesiano. ¿Cuál es entonces su posible entidad empíri$\mathrm{ca}$ ?

Aquí te acecha el insondable espejo

Que soñará y olvidará el reflejo

De tus postrimerías y agonías ${ }^{30}$.

Vida, sueño, espejo, olvido... Al modo de las cajas chinas, los conceptos van imbricándose en un proceso que hace etérea, falaz e inaprensible la identidad humana. Borges parte de símbolos barrocos (no puede serlo más el espejo, "vanidad de vanidades» y fugacidad de la belleza). Pero salta a otros registros (Schopenhauer sigue siendo una presencia ineludible). Por eso, cada ser humano concreto, desde su «nada» que va más allá del famoso verso por él remedado — «en polvo, en nadie, en nada y en olvido» ${ }^{31}$ - se atreve a soñar a un Dios quizá mentiroso, en un desafio heredero de la modernidad: — «¿Hubo un Jardín o fue el Jardín un sueño? / [...] No fue sino una mágica impostura / De aquel Dios que soñés ${ }^{32}$ - Por desgracia el hablante lírico no es el demiurgo platónico: «Yo también soy un sueño fugitivo que dura / Unos días más que el sueño del prado y la blancura» ${ }^{33}$

29 Borges, 1989, III, p. 156.

30 Borges, 1989, II, p. 273.

31 Borges, 1989, II, p. 303.

32 Borges, 1989, II, p. 312.

33 Borges, 1989, III, p. 115. 
—dirá caracterizando mediante ese sintagma, «sueño fugitivo», al frágil ser humano-.

Una dinámica que mantendrá hasta sus últimos poemarios, La cifra y Los conjurados que, a pesar de girar en torno a la vejez o a la historia, no cejan en problemáticas que le acompañaron hasta la tumba ginebrina.

\section{El FATUM APLASTA AL SER HUMANO ¿O EXISTE UN MARGEN PARA EL LIBRE ALBEDRÍO?}

Calderón es un escritor moderno del que esperaríamos lo que nos da: una apuesta por la libertad de elección personal frente al fatum de la tragedia clásica. Sus personajes parecen abocados a la desesperación, encajados en un callejón sin salida, pero... siempre encuentran un resquicio de luz que se abre a la trascendencia. Estamos en la España de la Contrarreforma:

En el fondo laten las nuevas ideas de Lutero y Calvino sobre la naturaleza irremediablemente herida del hombre y la Predestinación. Contra estos conceptos lucha Calderón de la Barca, demostrando en su obra que el Destino inclina pero no fuerza la libertad humana ${ }^{34}$.

Entre los investigadores clásicos del dramaturgo español quizá haya sido Parker quien más a fondo investigó una cuestión apasionante en sí misma, aunque sus opiniones no sean compartidas por todos. No hay más que pensar en el mito de Sísifo, que despliega sus alas desde la mitología y pintura griegas (La Odisea, o los frescos de Polignoto en Delfos) hasta existencialistas como Albert Camus, que lo convierten en un símbolo del hombre contemporáneo aplastado por un trabajo rutinario y sin escape en un mundo inmanente.

En el escritor barroco, el motivo se entrelaza con el del sueño, no solo en La vida es sueño sino principalmente en El mágico prodigioso (1637), comedia hagiográfica que escenifica la vidas de dos mártires antioqueños del siglo III, San Cipriano y Santa Justina, y que tal vez constituya en su versión contrarreformista el punto de partida de la búsqueda del verdadero Dios que, sin desearlo, protagoniza Borges du-

34 Arana Caballero, 2009, p. 11. 
rante toda su vida. Considerada antiintelectualista por algunos, en realidad ejemplifica cómo la razón, ejercida con honradez, lleva a Dios. Pero además borda asuntos como la conversión, las alternativas cristianas a la desesperación y, por supuesto, el libre albedrío:

El libre albedrío se ejemplifica sobre todo en Justina [...] pero también afecta a Cipriano, capaz de rechazar el pacto diabólico, confiado en el perdón de Dios. Su conversión niega la desesperación y rehúye el suicidio (vv. 2723-30) apelando a la fe en la generosidad del Dios que ha protegido a Justina (vv. 2731-60, 3015-27) ${ }^{35}$.

Una comedia considerada por muchos la mejor de Calderón, cuyo rigor constructivo, convenciones dramáticas, sistemas metafóricos y simbólicos y rigurosa terminología escolástica ha trabajado con exhaustividad Arellano ${ }^{36}$ y que, lamentablemente, no podemos abordar aquí.

Sobre el libre albedrío en La vida es sueño es inevitable traer a colación el famosísimo monólogo de Segismundo en la Jornada primera (vv. 102-172), en décimas y estructurado en torno a la comparación del ser humano con otros elementos de la naturaleza (ave, bruto, pez, arroyo) y cuyo centro es el estribillo con variaciones: «¿y yo con más albedrío / tengo menos libertad?» (vv. 151-152). Una queja desgarrada en un personaje prisionero desde su nacimiento: es el modo más gráfico de transmitir el mensaje, de hacer reflexionar a un público mayoritariamente analfabeto. Andando el tiempo, Rubén Darío se presentará como portavoz de la crisis moderna a fines del XIx: con los mismos ingredientes (el reino vegetal, el animal y el hombre) elaborará un poema trágico, Lo fatal, en que el hombre se queja de su condición privilegiada. No obstante, a diferencia de los hombres del Barroco parece querer renunciar a ella: a mayor sensibilidad y conocimiento, mayor capacidad de dolor... pero esa es otra historia, que muestra el genio del poeta para convertir en arte las trágicas contradicciones del ser humano.

En la comedia calderoniana, aprovechando el larguísimo parlamento explicativo de los antecedentes e historia de su hijo, el rey

35 Arellano, 2006, p. 227.

36 2006, pp. 219-244. 
Basilio pondrá su palabra al servicio del mensaje calderoniano: «porque el hado más esquivo, / la inclinación más violenta, / el planeta más impío, sólo el albedrío inclinan, / no fuerzan el albedrío» (vv. 787791 ${ }^{37}$. Paradójicamente no sabe aplicarlo a sí mismo:

En Basilio, no menos que en Segismundo, se plantea el tema del destino y del libre albedrío. La supuesta sabiduría del rey ignora en su soberbia que el destino humano sólo puede ser influido por las estrellas, pero nunca determinado: el experimento que hace con su hijo no es legítimo $^{38}$.

$\mathrm{Y}$ es que el binomio fatum/libertad tiene mucho que ver con el autodominio, que lleva a la elección del bien; y no puede desprenderse del tema central, la dialéctica sueño/vida. En ambos, es necesario optar por el bien... «aprender a dominar una espontaneidad que para un gobernante es defecto gravísimo, pues el que gobierna ha de supeditar las pasiones al bien común» ${ }^{39}$.Y eso lo conseguirá mediante la razón apoyada por la fe:

el hombre necesita de las dos para salvarse y encaminarse hacia Dios. El desengaño pesimista no surge, pues, en Calderón, del sentimiento de incapacidad o de las contradicciones entre fe y racionalismo o un hipotético ateísmo, sino de la realidad de una condición humana dañada por el pecado, y sujeta, por lo mismo, a múltiples servidumbres ${ }^{40}$.

Por el contrario, la poesía de Borges nunca es voluntarista, si bien el arranque de Elogio de la sombra: «La vejez (tal es el nombre que los otros le dan) / Puede ser el tiempo de nuestra dicha. El animal ha muerto o casi ha muerto, / Quedan el hombre y su alma»"11, se mueve en un senequismo o neoestoicismo que quizá no difiera mucho en los resultados. ¿Podría cifrarse de calderoniano? Tal vez sea forzar demasiado la cuerda... Porque si transcribimos el inicio de "In memoriam A.R.»: «El vago azar o las precisas leyes / Que rigen este sueño,

37 También a favor del libre albedrío vv. 1284-1287, vv. 1450-1451, vv. 31123119 , vv. 3255-3258

38 Arellano, 2006, p. 31.

39 Arellano, 2001, p. 78.

40 Arellano, 2001, p. 32.

41 Borges, 1989, III, p. 395. 
el universo» ${ }^{42} \ldots$ percibiremos un cierto aroma a fatum griego, con sutiles variantes, que implican al ser humano ${ }^{43}$. Aroma que irá in crescendo según continuemos la lectura, aunque en «Poema de la cantidad» el poeta parece esforzarse en buscarle un sentido al caos (no otra cosa había hecho en «La biblioteca de Babel»):

Acaso cada hormiga que pisamos

Es única ante Dios, que la precisa

Para la ejecución de las puntuales

Leyes que rigen su curioso mundo.

Si así no fuera, el universo entero

Sería un error y un oneroso caos ${ }^{44}$.

Tanto el cosmos como el yo son un sueño en manos del destino:... «Quizá el destino humano / De breves dichas y de largas penas / Es instrumento de Otro. Lo ignoramos; / Darle nombre de Dios no nos ayuda» ${ }^{45}$.Y el yo no es sino un pelele. "El porvenir es tan irrevocable como el rígido ayer» inscrito en el libro del tiempo. Por ello la metáfora del mundo, libro de Dios para los románticos, herencia platónica que permitía una relación analógica en libertad, ahora ha dejado de tener sentido para el cosmos, para el hombre e incluso para el mismo Dios:

Y siente que los actos que ejecuta
Interminablemente en su crepúsculo
Obedecen a un juego que no entiende
y que dirige un dios indescifrable ${ }^{46}$.

42 Borges, 1989, II, p. 207.

43 «El claro azar o las secretas leyes / Que rigen este sueño, mi destino» (Borges, 1989, II, p. 212); «Los números que rigen tu destino» (Borges, 1989, II, p. 302); «Que es mi destino" (Borges, 1989, II, p. 365); «Es de hierro tu destino / Como tu juez» (Borges, 1989, II, p. 364); «En vano es vario el orbe. La jornada / Que cumple cada cual ya fue fijada» (Borges, 1989, III, p. 84)... En un segundo nivel, «los recuerdos sagrados y triviales / Que son nuestro destino" (Borges, 1989, III, p. 140).

44 Borges, 1989, II, p. 492.

45 Borges, 1989, III, p. 100.

46 Borges, 1989, III, p. 198. 
Ya lo había solventado con brillantez unos años antes en el párrafo final del ensayo "Nueva refutación del tiempo»: "And yet, and yet... Negar la sucesión temporal, negar el yo, negar el universo astronómico, son desesperaciones aparentes y consuelos secretos. Nuestro destino $[\ldots]$ es espantoso porque es irreversible y de hierro» ${ }^{47}$. La ambigüedad de los primeros tiempos, visible en poemas como «El truco» donde la doble perspectiva temporal, inmanente y trascendente, permitía un mínimo de libertad a los jugadores que sin saberlo repetían inexorablemente las jugadas previstas desde toda la eternidad por ese demiurgo; esa ambigüedad parece haber desaparecido. Y el hablante lírico, trasunto del ser humano, sufre las consecuencias.

\section{Pero ¿están tan lejos Calderón y Borges?}

La pregunta parece absurda pero tal vez no lo sea. En cuanto a la intencionalidad de su teatro, Calderón es un hombre culto educado en los jesuitas donde aprendió teología, además de gramática, griego y latín. Por no hablar de sus estudios universitarios en Alcalá y Salamanca, que redondearon sus conocimientos de derecho, lógica y retórica. Aún así no pretende adoctrinar sin más: la máquina teatral es un artefacto al servicio del público, al que quiere conmover antes que convencer. Un punto de contacto con Borges cuyo interés prioritario es escribir «el libro, la obra» que le convierta en clásico ${ }^{48}$.

Por lo que se refiere a los planteamientos gnoseológicos u ontológicos de sus textos, ambos son deudores de la filosofia y la cosmovisión de su época. Para el escritor barroco y en línea con la herencia de los estoicos, el objetivo era que la razón rechazara las apariencias falaces; es decir, delimitar la frontera entre verdad y mentira, y elegir el bien. Algo que distancia, incluso enfrenta radicalmente a Calderón y a un Borges que se mueve con soltura en la ambigüedad y las contradicciones de un mundo relativista. Que incluso juega con ellas, apoyado en figuras retóricas como la antítesis o el emblemático oxymoron... Por el contrario, y aunque para los estoicos la vida sea una comedia y el mundo un teatro, siempre - incluso en sueños- hay que obrar bien. La lección ética ante todo.

47 Borges, 1989, II, p. 149.

48 Caballero Wangüemert, 1999. 
Neoestoicismo... pero también filosofía moderna (Descartes), como fuente ideológica inmediata de La vida es sueño y la producción calderoniana en general. Aunque no consta las conociera, en las Meditaciones metafísicas (1641) el francés señala tres pasos relacionados con la duda metódica: el engaño de los sentidos, la dificultad de distinguir sueño y realidad; y la hipótesis del genio maligno que nos hace dudar de las proposiciones matemáticas. Rivera de Rosales ha propuesto un proceso similar en Calderón, no estructurado formalmente sino en metáforas, según el cual sus obras rezumarían

un desengaño dramatizado en relación con la realidad del mundo, para descubrir al final de ese camino el carácter superior de la libertad y de sus obras. Se podría articular dicho proceso también en tres grandes momentos: el valor teórico de lo sensible, el plano de la coherencia o valor conceptual y el alcance real de lo afectivo y deseado ${ }^{49}$.

Lo sensible como apariencia engañosa debido a la falta de información, o al desborde de la fantasía, o a las continuas tretas de los personajes; el proceso que desdibuja la pretendida coherencia del mundo, cuando esa coherencia debería funcionar como criterio delimitador entre sueño y realidad; y el deseo, el dolor y la muerte como elementos tangibles de realidad funcionarían en el dramaturgo barroco, pero con fisuras que, curiosamente lo acercan a Borges: por ejemplo, cuando afirma "el mundo real es común y compartido, de modo que su coherencia en verdad la tejemos entre todos». ¿Esto no suena a "Amanecer»? O cuando realza los aspectos contradictorios y los juegos de contrarios en los títulos, al modo de «Sueños hay que son verdad» $\mathrm{o}$ "En este mundo todo es verdad y todo es mentira»... O cuando debe enfrentarse al problema del mal, a un cosmos carente de plenitud («mal hecho» — diría Borges—; «debido a un dios inepto, incapaz o perverso»; "un genio maligno» — diría Descartes-).

A este substrato ideológico se superpone el mensaje católico y contrarreformista de Calderón, mucho más visible en su segunda etapa, ya ordenado sacerdote. Y mucho más vertido hacia el auto sacramental, tal vez por voluntad propia, o quizá como fruto de ciertas con-

49 Rivera de Rosales, 2008, p. 442. 
troversias que protagonizara muy a su pesar ${ }^{50}$. Entonces jjuega con red Calderón y acertarían quienes — como Parker - niegan la existencia de la tragedia en el marco de una cosmovisión religiosa... «que contempla la presencia de un Dios ordenador y justo y un más allá en que todo desorden se subsana?» ${ }^{51}$. O, como sugiere el mismo investigador, «aunque el marco ideológico general de Calderón es sin duda el cristianismo, no siempre es operativa en el plano dramático la esperanza del más allá» ${ }^{52}$, lo que permite plasmar los dilemas del ser humano en el escenario a nivel trágico. No hay más que disociar el hombre y su obra, o hilar más fino: porque no pueden equipararse sin más las comedias, los dramas y los autos del español en cuanto a su mensaje "religioso».

¿Y si, en una nueva vuelta de tuerca, tuviera razón Borges cuando afirma que para Calderón, «esencialmente cristiano», «lo verdadero son el cielo y el infierno» ${ }^{53}$ ? Solamente que esta simplificación habría que aplicarla al auto sacramental, en el que suele ofrecer

... una versión alegorizada de un tema profano tratado con anterioridad. Al estar delimitado por el dogma, el auto La vida es sueño condensa la problemática de la vida-sueño haciendo caso omiso de las complejas significaciones que ha presentado el drama. Calderón hace una valoración teológica del tema de la vida como sueño. Vivir en el sueño es, según afirma la Sombra al hombre, vivir prisionero de vanidades terrestres, de las ilusiones pasajeras y del engaño de los sentidos que conducen al error. El pesimismo del autor se limita al mundo terreno, a la vida material. La muerte no es la nada, sino el despertar a otra vida, una vida sobrenatural garantizada por la fe y las buenas obras ${ }^{54}$.

50 Nos referimos a la conocida polémica que generaron Agustín de Herrera y los jesuitas denunciando su teatro, al caracterizar su comedia como... «obscena, corrosiva y peligrosa para el bien de las almas» (Jeske, 2008, p. 288), opuesta a la moral cristiana, inductora de concupiscencias y subversiva para la religión. Más allá del posible conflicto entre órdenes, tal vez ponga de manifiesto que «la visión hoy dominante de Calderón como autor que utiliza el teatro para propagar una visión católica del mundo no fue compartida por sus contemporáneos» — concluye Jeske- (2008, p. 293).

51 Arellano, 2001, p. 25.

52 Arellano, 2001, p. 25.

53 Sorrentino, 2001, p. 133.

54 Sabik, 1998, pp. 110-111. 
Ante la vida humana, frágil y fugaz tránsito de la cuna a la sepultura, Calderón se refugia en la libertad y el orden moral. Por lo que el estatuto mundano adquiere un valor relativo. Ante la desconfianza frente a los sentidos y la subsiguiente duda metódica, Descartes se refugia en el cogito. Pero, al hacerlo, abre la espita al relativismo de la posmodernidad. Posmoderno o no, para Borges, el cogito es tan irrelevante, tan inasible como asidero que...

\section{A MODO DE CONCLUSIÓN}

Abríamos el artículo relacionando a Borges con el Barroco. Pues bien: las resonancias barrocas en los versos del argentino son indudables; especialmente aplicadas al yo del hablante lírico. Unos versos de La moneda de hierro pueden servir para ejemplificarlo y, a la vez, marcar las distancias entre dos épocas, dos literaturas, dos autores, Calderón y Borges:

En ese laberinto puro está tu reflejo.

Arrojemos de nuevo la moneda de hierro

Que es también un espejo mágico. Su reverso

Es nadie y nada y sombra y ceguera. Eso eres [...]

Dios es el inasible centro de la sortija.

No exalta ni condena. Obra mejor: olvida ${ }^{55}$.

Cárcel o laberinto, el mundo fue problemático para el hombre desde los antiguos que encerraron en él al minotauro o a Segismundo. Pero había una esperanza, una tarea que realizar, un reto que daba sentido a la vida humana y sus acciones tendían a culminarlo. Y un Dios providente... Para Borges y según la poesía que examinamos aquí, todo dejó de tener sentido. De modo que sus versos tan barrocos «Soy el que sabe que no es más que un eco $»^{56}$, «Soy eco, olvido, nada» ${ }^{57}$ difieren radicalmente de la cosmovisión cristiana del XVII, no tienen detrás un referente abierto a la trascendencia.

55 Borges, 1989, III, p. 160.

56 Borges, 1989, III, p. 196.

57 Borges, 1989, III, p. 89. 
¿O sí? Porque a lo que, de verdad, teme el escritor es a la inmortalidad: «Borges teme ser para toda la eternidad él mismo porque sería muy aburrido. No quisiera que su finitud, su monótona y tediosa finitud, se extendiera indefinidamente» — dice Zagal Arreguín ${ }^{58}$ no sin razón-. Para avalarlo, están sus declaraciones en múltiples entrevistas. Mejor aún, sus propios versos, tan reiterativos en ocasiones. En El otro, el mismo se suceden dos sonetos de textura muy barroca, "Everness» y «Ewigkeit», y complementarios al respecto:

Solo una cosa no hay. Es el olvido

Dios, que salva el metal, salva la escoria ${ }^{59}$.

Siempre inmerso en paradojas y contradicciones... «Borges, usando un vocablo que le gusta, ha fatigado la historia de las religiones, los catálogos de sectas y herejías, las antologías filosóficas y las recopilaciones de mitos, sin encontrar una creencia en la que pueda reconocerse, un Dios en el que su espíritu fuera capaz de reposar» ${ }^{60}$. Frente al cristianismo despliega una "lejana cercanía» ${ }^{61}$, jugando una y otra vez con sus conceptos y metáforas; pero, a diferencia de Calderón $\mathrm{y}$ «heredero de la tradición moderna, Borges se cree autorizado a llamar a juicio al Dios cristiano para imputarle los males del mundo y condenarle, llegado el caso, a la pena de inexistencia» ${ }^{62}$. Su poema «Cristo en la cruz», de Los conjurados muestra los límites de quien fue incapaz de imaginar un Dios providente y amoroso, eterna promesa de felicidad para su creación: el hombre. Lo protestante y luterano de la abuela paterna, muy teñido de Antiguo Testamento (Dies irae) ha pesado mucho más en su cosmovisión que la enseñanza materna. Y eso tuvo sus consecuencias. Pero el argentino está muy marcado por la herencia religiosa de sus mayores, no es un relativista a la moda. Para concluir sin cerrar una cuestión que Kodama afirma le persiguió hasta el lecho de muerte, diríamos:

58 Zagal Arreguín, 1999, p. 183.

59 Borges, 1989, II, p. 305.

60 Arana, 1994, p. 99.

61 Zagal Arreguín, 1999, p. 182.

62 Arana, 1994, p. 83. 
Goethe lamentaba que Shakespeare no hubiera podido conocer a Calderón pues pensaba que el mismo autor de Hamlet podría haber aprendido del español ${ }^{63}$.

Lamentamos que Borges no haya buceado con mayor profundidad en las obras del escritor Barroco, porque además de disfrutar con su máquina escénica, tan redonda, tal vez hubiera conseguido, antes de su muerte, entreabrir un poco más esa puerta del más allá, teñida ¿o no? de arquetipos y resplandores; y así reposar su pertinaz, casi eterna búsqueda.

63 Arellano, 2001, p. 125. 


\section{Bibliografía}

Ara, J., Bibliografía comentada de "La vida es sueño», New York, Peter Lang, 1996.

Arana, J., El centro del laberinto. Los motivos filosóficos en la obra de Borges, Pamplona, EUNSA, 1994.

Arana Caballero, R., Introducción a Pedro Calderón de la Barca. La vida es sueño, Sevilla, Fundación de Cultura Andaluza, 2009, pp. 9-33.

Arellano, I., Diccionario de los autos sacramentales de Calderón, Kassel, Reichenberger, 2000.

- Calderón y su escuela dramática, Madrid, Ediciones del Laberinto, 2001.

- El escenario cósmico. Estudios sobre la comedia de Calderón, Madrid / Frankfurt, Iberoamericana / Vervuert, 2006.

- Cilveti, Á. L., Bibliografía crítica sobre el auto sacramental, Kassel, Reichenberger, 1994.

- y Cancelliere, E. ed., La dramaturgia de Calderón. Técnicas y estructuras (Homenaje a Jesús Sepúlveda), Madrid / Frankfurt, Iberoamericana / Vervuert, 2006.

Arenz, S., "Algunas notas sobre la presencia de Pedro Calderón de la Barca en Hispanoamérica»:

http://bib.cervantesvirtual.com/bib_autor/Calderon/arenz.html (Consultado el 30-IX-2012).

Aszyk, U., «El mágico prodigioso: entre la comedia de santos y la comedia de magia, un modelo teatral en evolución», en Calderón y su escuela: variaciones e innovación de un modelo teatral. XV Coloquio Anglogermano sobre Calderón, Wroclaw, 14-18 de julio 2008, ed. M. Tietz y G. Arnscheidt, en colaboración con B. Baczynska, Stuttgart, Franz Steiner Verlag, 2010, pp. 13-22.

Barrachina, R., El libre albedrío en ocho dramas religiosos de Calderón de la Barca, Dissertation Abstracts International, 47:4, 1346, 1986.

Borges, J. L., Obras completas I-III, Barcelona, Emecé, 1989.

- Textos recobrados (1919-1929), Buenos Aires, Emecé, 1997.

- Cartas del fervor. Correspondencia con Maurice Abramowicz y Jacobo Sureda (1919-1928), Barcelona, Galaxia Gutenberg / Círculo de Lectores, Emecé, 1999a.

- Un ensayo autobiográfico, edición del Centenario (1899-1999), ilustrado con imágenes de su vida, prólogo A. González, epílogo M. Kodama, Barcelona, Galaxia Gutenberg / Círculo de Lectores / Emecé, 1999b.

- Siete noches, México, Fondo de Cultura Económica, 1999c.

- Textos recobrados (1931-1955), Barcelona, Emecé, 2002. 
Busquets, L., "Borges y el Barroco», Cuadernos Hispanoamericanos. Homenaje a José Luis Borges, Madrid, 505-507, 1992, pp. 299-319.

Caballero Wangüemert, M., Borges y la crítica. El nacimiento de un clásico, Madrid, Universidad Complutense, 1999.

- «Borges y el canon: la literatura española», en El laberinto de los libros: Jorge Luis Borges frente al canon literario, ed. A. de Toro, Hildesheim, Olms, 2007, pp. 101-118.

Calderón de la Barca, P., Comedias. Nueve partes, ed. dirigida por M. C. Simón Palmer, Madrid, Chadwyck-Healey España. CD Rom. (Teatro Español del Siglo de Oro), 1998.

- El mágico prodigioso, ed. B. Wardropper, Madrid, Cátedra, 1985.

- Auristela y Lisidante, ed. R. Arana, Madrid / Frankfurt, Iberoamericana / Vervuert, 2012.

Campbell, Y., La vida es sueño a la luz del pensamiento neoestoico-tacitista, México, El Colegio de México, 2009.

Cilveti, Á. L., El significado de "La vida es sueño», Valencia, Albatros, 1971.

Cortínez, C. (ed.), Borges the Poet, Fayeteville, University of Arkansas Press, 1986.

Cheselka, P., The Poetry and Poetics of Jorge Luis Borges, New York, Peter Lang, 1987.

De Barone, L. y A. J. Sáez, «Bibliografia sobre Calderón», Anuario Calderoniano, 4, 2010, pp. 483-507.

De Toro, A., "Cervantes, Borges y Foucault: la realidad como viaje a través de los signos», en El siglo de Borges, ed. K. L. Blüher y A. de Toro, Madrid / Frankfurt, Iberoamericana / Vervuert, 1999, vol. II, pp. 45-65.

FERNÁNDEZ, T., «Jorge Luis Borges frente a la literatura española», en J.Alazraki et al., España en Borges, Madrid, El Arquero, 1990, pp. 23-37.

FINE, R., «Borges y Cervantes: perspectivas estéticas», en Borges en Jerusalén, ed. M. Solotorevsky y R. Fine, Madrid / Frankfurt, Iberoamericana / Vervuert, 2003, pp. 117-125.

Gilbert, F., «El sueño como personaje alegórico en dos autos de Calderón, La siembra del Señor (antes de 1655) y Sueños hay que son verdad (1670)", Bulletin of The Comediantes, 60, núm. 1, 2008, pp. 91-126.

Gomollón, B., «Edipo y Segismundo: la libertad en Sófocles y Calderón», Lectura y signo, revista de Literatura, 3, 2008, pp. 309-322.

Jeske, C. M., "Calderón frente al catolicismo: la polémica jesuítica contra el teatro calderoniano", en Calderón y el pensamiento ideológico y cultural de su época. Actas del XIV Coloquio Anglogermano sobre Calderón (Heidelberg, 2428 julio 2005), ed. M. Tietz y G. Anscheidt, Stuttgart, Franz Steiner, 2008, pp. 285-297. 
Kumor, K. (ed.), De Cervantes a Calderón: estudios sobre la literatura y el teatro español del Siglo de Oro. Homenaje al profesor Kazimierz Sabik, Varsovia, Universidad de Varsovia, 2009.

Lafuente, R. F. (coord.), España en Borges, Madrid, El Arquero, 1990.

Macrobio, Comentario al Sueño de Escipión de Cicerón, Madrid, Gredos, 2006.

- Comentarios al Sueño de Escipión, Madrid, Siruela, 2005.

Madrid, L., Cervantes y Borges: la inversión de los signos, Madrid, Pliegos, 1987.

Morón Arroyo, C., Calderón, pensamiento y teatro, Santander, Sociedad Menéndez Pelayo, 1982.

— «Los autos sacramentales y la historia de la salvación», en La dramaturgia de Calderón. Técnicas y estructuras (Homenaje a Jesús Sepúlveda), ed. I. Arellano y E. Cancelliere, Madrid / Frankfurt, Iberoamericana / Vervuert, 2006, pp. 305-324.

Nahson, D., La crítica del mito. Borges y la literatura como sueño de vida, Madrid / Frankfurt, Iberoamericana / Vervuert, 2009.

Olmedo, F. G., Las fuentes de "La vida es sueño", Madrid, Voluntad, 1928.

Parker, A., Los autos sacramentales de Calderón, Barcelona, Ariel, 1983.

- La imaginación y el arte de Calderón, Madrid, Cátedra, 1991.

Pedraza, F., Calderón. Vida y teatro, Madrid, Alianza, 2000.

Poppenberg, G., «La estructura de la acción del auto sacramental. Reflexiones generales y un ejemplo: La vida es sueño», en La dramaturgia de Calderón. Técnicas y estructuras (Homenaje a Jesús Sepúlveda), ed. I. Arellano y E. Cancelliere, Madrid / Frankfurt, Iberoamericana / Vervuert, 2006, pp. 377-388.

Regalado, A., Calderón. Los orígenes de la modernidad en la España del Siglo de Oro, Barcelona, Destino, 1995, 2 vols.

Revista Iberoamericana. 40 Inquisiciones sobre Borges, ed. A. Roggiano y J. Alazraki, Pittsburgh, 43, julio-diciembre 1977, pp. 100-101.

Rivera de Rosales, J., "Calderón y la filosofía moderna», en Calderón y el pensamiento ideológico y cultural de su época. Actas del XIV Coloquio Anglogermano sobre Calderón (Heidelberg, 24-28 julio 2005), ed. M. Tietz y G. Anscheidt, Stuttgart, Franz Steiner, 2008, pp. 441-459.

Ruiz Ramón, F., Calderón y la tragedia, Madrid, Alhambra, 1984.

SABIK, K., «La problemática del sueño en el teatro español de la segunda mitad del siglo XVII", en Sogno e scrittura nelle culture iberiche. Atti del XVII Convegno, Milano 24-26 ottobre 1996, Roma, Bulzoni, 1998, pp. 109-121.

Sorrentino, F., Siete conversaciones con Jorge Luis Borges, Buenos Aires, El Ateneo, 2001.

Sucre, G., Borges el poeta, México, UNAM, 1967.

SChwARTz, L., "Calderón y la cultura europea. De la imaginación onírica en La vida es sueño", en http://cvc.cervantes.es/literatura/calderon_europa/schwartz.htm (Consultado el 28-IX-2012). 
Tietz, M. y G. Anscheidt (ed.), Calderón y el pensamiento ideológico y cultural de su época. Actas del XIV Coloquio Anglogermano sobre Calderón (Heidelberg, 24-28 julio 2005), Stuttgart, Franz Steiner, 2008.

Unamuno, M. de, Obras completas, VII, ed. M. García Blanco, Madrid, Las Ámericas / Escelier, 1969.

Vega García-Luengos, G.; D. W. Cruickshank y J. M. ${ }^{a}$ Ruano de la Haza, La segunda versión de La vida es sueño de Calderón, Liverpool, Liverpool University Press, 2000.

- «Nuevos aspectos intertextuales de La vida es sueño (con indicios del Calderón extracanónico)», en La dramaturgia de Calderón. Técnicas y estructuras (Homenaje a Jesús Sepúlveda), ed. I. Arellano y E. Cancelliere, Madrid / Frankfurt, Iberoamericana / Vervuert, 2006, pp. 587-607.

Williamson, E., Borges. Una vida, traducción E. E. Gandolfo, Barcelona, Seix Barral, 2007.

Zagal Arreguín, H. (ed.), "El cristianismo de Borges», en Ocho ensayos sobre Borges, México, Cruz O.S.A., 1999, pp. 181-203.

Zweig, S., Castellio contra Calvino. Conciencia contra violencia, traducción B.Vias Mahou, Barcelona, Acantilado, 2001. 